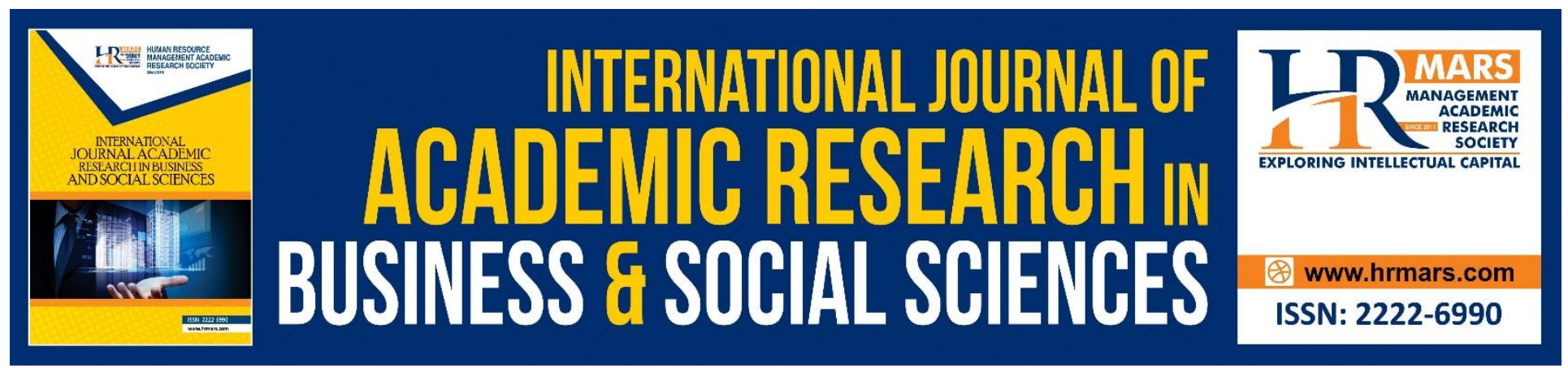

\title{
Does Coworkers Support Matters? Employee Engagement Study in Malaysia Oil and Gas Offshore Operations
}

Ridwan Mokhtar, Sylvia Nabila Azwa Ambad, Sharifah Nurafizah Syed Annuar, Nelson Lajuni

To Link this Article: http://dx.doi.org/10.6007/IJARBSS/v10-i7/7412

DOI:10.6007/IJARBSS/v10-i7/7412

Received: 07 April 2020, Revised: 10 May 2020, Accepted: 24 June 2020

Published Online: 24 July 2020

In-Text Citation: (Mokhtar et al., 2020)

To Cite this Article: Mokhtar, R., Ambad, S. N. A., Annuar, S. N. S., \& Lajuni, N. (2020). Does Coworkers Support Matters? Employee Engagement Study in Malaysia Oil and Gas Offshore Operations. International Journal of Academic Research in Business and Social Sciences, 10(7), 232-244.

Copyright: (C) 2020 The Author(s)

Published by Human Resource Management Academic Research Society (www.hrmars.com)

This article is published under the Creative Commons Attribution (CC BY 4.0) license. Anyone may reproduce, distribute, translate and create derivative works of this article (for both commercial and non-commercial purposes), subject to full attribution to the original publication and authors. The full terms of this license may be seen at: http://creativecommons.org/licences/by/4.0/legalcode

Vol. 10, No. 7, 2020, Pg. 232 - 244

http://hrmars.com/index.php/pages/detail/IJARBSS

JOURNAL HOMEPAGE

Full Terms \& Conditions of access and use can be found at http://hrmars.com/index.php/pages/detail/publication-ethics 


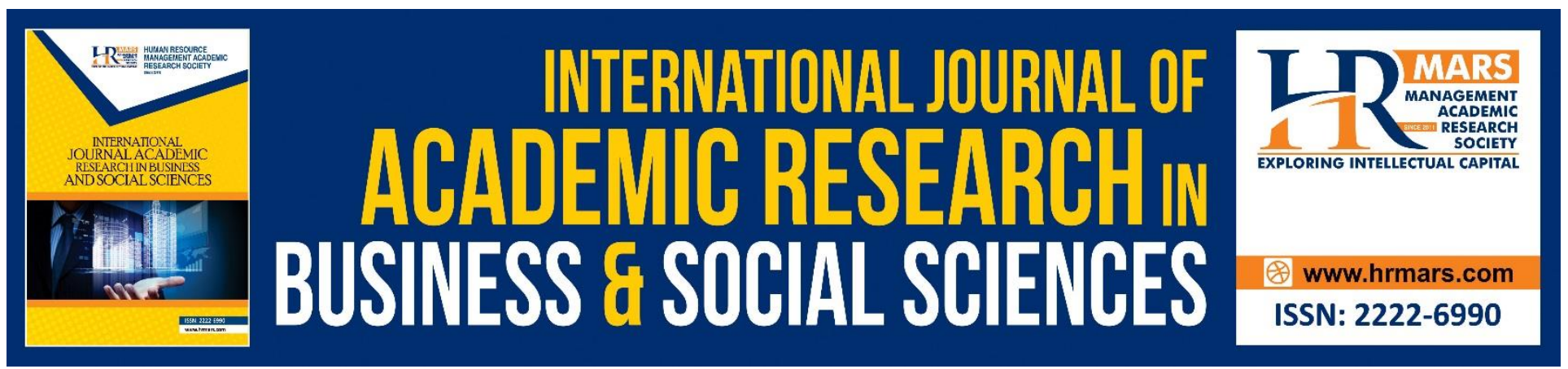

\title{
Does Coworkers Support Matters? Employee Engagement Study in Malaysia Oil and Gas Offshore Operations
}

\section{Ridwan Mokhtar ${ }^{1}$, Sylvia Nabila Azwa Ambad², Sharifah Nurafizah Syed Annuar ${ }^{3}$, Nelson Lajuni ${ }^{4}$}

${ }^{1}$ Arshad Ayub Graduate Business School, Universiti Teknologi MARA (UiTM), Sabah Branch, Kota Kinabalu Campus, Malaysia, ${ }^{2}$ Faculty of Business and Management, Universiti Teknologi MARA (UiTM), Sabah Branch, Kota Kinabalu Campus, Malaysia, ${ }^{3}$ Faculty of Business and Management, Universiti Teknologi MARA (UiTM), Sabah Branch, Kota Kinabalu Campus, Malaysia, ${ }^{4}$ Faculty of

Business, Economics and Accountancy, Universiti Malaysia Sabah (UMS), Malaysia

Email: drridwanmokhtar@gmail.com,nabilazwa@gmail.com,shnurafizah@gmail.com, nlajuni@gmail.com

\begin{abstract}
With the new norm in business environment post-COVID-19 outbreak in late 2019, most of the organisation struggles in adapting to address unprecedented changes that indirectly affect the organisation's relationships with its own employees. Thus, employee engagement still remains a relevant subject to be discussed. There were limited studies that have been carried out on the impacts of coworkers support on employee engagement, especially in the Malaysian oil and gas industry. Therefore, this study examines the effects of coworkers support towards employee engagement among the offshore employees in Malaysia. A study was conducted through an online questionnaire via Google Forms approach where 250 offshore employees participated and data were then analysed by utilizing Partial Least Squared-Structural Equation Modelling using SmartPLS 3.0. The findings suggest that coworkers support has a positive relationship with both employee engagement dimensions among offshore employees. This study had provided oil and gas companies with a better insight and understanding of the importance of the coworkers support aspect in improving employees' level of employee engagement among offshore employees. Future studies should also consider examining whether supervisor support and management support at offshore locations play an important role in enhancing the level of employee engagement.
\end{abstract}

Keywords: Employee Engagement, Coworkers Support, Oil and Gas, Offshore Employee.

\section{Introduction}

In the past few decades, there has been abundance research of concentration in relation to employee engagement. Employee Engagement was defined as the "harnessing of organisation members' selves 
to their work roles: in engagement, people employ and express themselves physically, cognitively, emotionally, and mentally during role performances" (Khan, 1990). Employee engagement has been categorized into two types: job engagement and organisational engagement. Job engagement refers to the extent to which an individual is actually fascinated in the performance of his/her own individual job role. Meanwhile, organisational engagement reflects "the extent to which an individual is psychologically present as a member of an organisation" (Saks, 2006). To date, there are limited number of researches that have been conducted in the oil and gas industry based on Malaysia context specifically on employee engagement. Therefore, by conducting this study, it will provide a clear perspective with respect employee engagement that suits to the context of Malaysia especially in offshore working environment. Therefore, this exploratory study will examine the relationship between coworkers support and employee engagement.

\section{Literature Review}

\section{Employee Engagement}

Engagement has been widely known as a central research subject in organisational science (Sonnentag, 2011). Employee Engagement was defined as the "harnessing of organisation members' selves to their work roles: in engagement, people employ and express themselves physically, cognitively, emotionally, and mentally during role performances" (Khan, 1990). The cognitive dimension of employee engagement includes workers' beliefs in the organisation, its members and working conditions. The emotional dimension concerns how workers feel towards each of these three aspects and how they have positive or pessimistic feelings about the company and its members. The physical dimension of workplace involvement involves the physical efforts of employees to carry out their duties. To accomplish this dedication, Kahn (1990) suggested three antecedents: psychological availability, psychological safety, and psychological meaningfulness (Khan 1990). Despite this, employee engagement was characterized as the psychological presence of employees during work, which includes two critical components, namely attention and absorption (Rothbard, 2001). Employee engagement is an optimistic, rewarding and psychological state of mind characterized by vigor, dedication and absorption (Schaufeli et al., 2002). The conceptualization of employee engagement as a multi-dimensional structure was characterized as the degree to which the worker is attentive and immersed in the performance of his / her positions. Employee engagement has been divided into two types: job engagement and organisational engagement. Job involvement refers to the degree to which a person is genuinely intrigued by the success of his / her own particular work role. In the meantime, organisational involvement represents "the degree to which a person is mentally present as a part of an organisation" (Saks, 2006).

\section{Coworkers Support}

Perceived organisational support is defined as the employees' beliefs concerning the extent to which the organisation values their contribution and cares about their well-being (Eisenberger et al., 1986). According to Organisational Support Theory (OST) (Eisenberger, Huntington, Hutchison, \& Sowa, 1986; Eisenberger \& Stinglhamber, 2011), employees develop a general perception concerning the extent to which the organisation values their contributions and cares about their well-being. Based on the argument by Eisenberger et al., (1986), employees perceive an organisation a comparable means of a human being and acts are reflected to be the acts of human being. Correspondingly, agents performing tasks for the organisation are itself organisation and their actions will be actions 
INTERNATIONAL JOURNAL OF ACADEMIC RESEARCH IN BUSINESS AND SOCIAL SCIENCES Vol. 10, No. 7, July, 2020, E-ISSN: 2222-6990 @ 2020 HRMARS

of organisation, as Levinson (1965), mentioned that demands and moods of agents will define the demands and moods of the organisation. Care from the management or employees will be reflected as the care from the organisation. This agency position is not only given to supervisor or leader, rather employees or coworkers, are also agents of organisation, as they are also representative of organisation. So, it can be indirectly perceived that organisation is having agency relationship with all of its employees. From an employee perspective it can be inferred that there are two types of agents or representative of any organisation i.e. supervisor or leader and the other one is coworkers or peers. Based on recent research, coworkers feedback can be used to supplement the lack of supervisor feedback when required (Eva et. al., 2019). Therefore, organisational support will include support from organisation or management, support from supervisor and support from coworkers or peers. The aforesaid literature is evident that support from co-workers or peers can influence positively employees' perception of support from organisation. Therefore, it is predicted that coworkers support will be related to employee engagement (job and organisational engagement) as follows;

$\mathrm{H}_{1}$ : $\quad$ Coworkers support will be positively related to job engagement

$\mathrm{H}_{2}$ : $\quad$ Coworkers support will be positively related to organisational engagement

\section{Data and Methodology}

For this purpose of this study, 250 respondents have been participated where only 234 samples were usable in which it has been segregated to respondents by each region within Malaysia namely Sabah, Sarawak and Peninsular Malaysia. The data for this study was collected through online questionnaire and blast to oil and gas operators focal through "Snowball approach" before disseminating the online questionnaire via Google forms to their respective offshore employees. Participants were asked to complete the survey as part of study on the relationship of coworkers support and employee engagement. Participation was on voluntary basis and participant were informed that their responses would remain confidential. Table 1 presents the demographic information of respondents. 
INTERNATIONAL JOURNAL OF ACADEMIC RESEARCH IN BUSINESS AND SOCIAL SCIENCES Vol. 10, No. 7, July, 2020, E-ISSN: 2222-6990 @ 2020 HRMARS

\section{Table 1 - Demographic Information on Respondents}

\begin{tabular}{|c|c|c|c|}
\hline Variable & & Frequency & $\begin{array}{l}\text { Percent } \\
(\%)\end{array}$ \\
\hline \multirow{2}{*}{ Gender } & Male & 211 & 90.2 \\
\hline & Female & 23 & 9.8 \\
\hline \multirow{4}{*}{$\begin{array}{l}\text { Marital } \\
\text { Status }\end{array}$} & Single & 48 & 20.5 \\
\hline & Married & 184 & 78.6 \\
\hline & Widow & 1 & 0.4 \\
\hline & Widower & 1 & 0.4 \\
\hline \multirow{5}{*}{ Education } & Doctorate & 0 & 0.0 \\
\hline & Master & 6 & 2.6 \\
\hline & Degree & 70 & 29.9 \\
\hline & Diploma & 98 & 41.9 \\
\hline & Others & 60 & 25.6 \\
\hline \multirow{6}{*}{ Race } & Malay & 91 & 38.9 \\
\hline & Chinese & 15 & 6.4 \\
\hline & Indian & 2 & 0.9 \\
\hline & Sabah Natives & 71 & 30.3 \\
\hline & Sarawak & 38 & 16.2 \\
\hline & Others & 17 & 7.3 \\
\hline \multirow{3}{*}{$\begin{array}{l}\text { Offshore } \\
\text { Work } \\
\text { Location }\end{array}$} & \multirow{3}{*}{$\begin{array}{l}\text { Sabah } \\
\text { Sarawak } \\
\text { Peninsular } \\
\text { Malaysia }\end{array}$} & 78 & 33.3 \\
\hline & & 78 & 33.3 \\
\hline & & 78 & 33.3 \\
\hline \multirow{3}{*}{$\begin{array}{l}\text { Offshore } \\
\text { Working } \\
\text { Tenure }\end{array}$} & $\begin{array}{l}\text { Less than } 2 \\
\text { years }\end{array}$ & 30 & 12.8 \\
\hline & $\begin{array}{lll}\text { From } 2-5 \\
\text { years }\end{array}$ & 49 & 20.9 \\
\hline & $\begin{array}{l}\text { More than } 5 \\
\text { years }\end{array}$ & 155 & 66.2 \\
\hline
\end{tabular}

\section{Conceptual Framework}

This study will further explore the relationship of coworkers support towards employee engagement as shown in Figure 1.

Figure 1 - Conceptual framework

Perceived Organisational Support

Employee Engagement

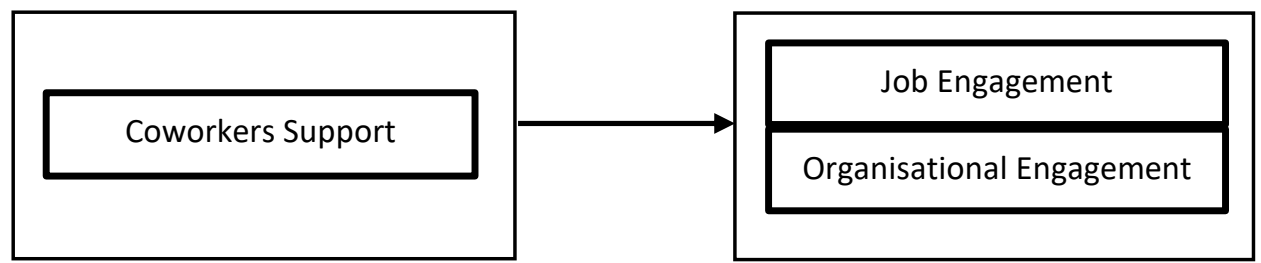


INTERNATIONAL JOURNAL OF ACADEMIC RESEARCH IN BUSINESS AND SOCIAL SCIENCES Vol. 10, No. 7, July, 2020, E-ISSN: 2222-6990 @ 2020 HRMARS

\section{Estimation Procedure}

The survey questionnaire is comprised of three parts. Part 1 obtains respondents' demographic information. Part 2 measures the employee engagement by adopt and adapt using eleven items taken from Saks (2006). The final part of the questionnaire measure on coworkers support which contains six items that were adopt and adapt from Hammer et al., (2004).

\section{Table 2 - Sample Measurement Items and Sources}

\begin{tabular}{|c|c|c|c|}
\hline Construct & Dimension & Sample Items & Source \\
\hline \multirow{6}{*}{$\begin{array}{l}\text { Employee } \\
\text { engagement }\end{array}$} & & 1. I really throw myself into my job & \multirow{6}{*}{$\begin{array}{l}\text { Saks } \\
(2006)\end{array}$} \\
\hline & $\begin{array}{l}\text { Job } \\
\text { engagement }\end{array}$ & $\begin{array}{l}\text { 2. Sometimes I am so into my job that I lose } \\
\text { track of time }\end{array}$ & \\
\hline & & 3. I am highly engaged in this job & \\
\hline & \multirow{3}{*}{$\begin{array}{l}\text { Organisational } \\
\text { engagement }\end{array}$} & $\begin{array}{l}\text { 1. Being a member of this organisation is very } \\
\text { captivating }\end{array}$ & \\
\hline & & $\begin{array}{l}\text { 2. One of the most exciting things for me is } \\
\text { getting involved with things happening in this } \\
\text { organisation }\end{array}$ & \\
\hline & & 3. I am highly engaged in this organisation & \\
\hline \multirow{3}{*}{$\begin{array}{l}\text { Perceived } \\
\text { Organisational } \\
\text { Support }\end{array}$} & \multirow{3}{*}{$\begin{array}{l}\text { Coworkers } \\
\text { Support }\end{array}$} & 1. I receive help from my coworkers & \multirow{3}{*}{$\begin{array}{l}\text { Hammer } \\
\text { et al., } \\
(2004)\end{array}$} \\
\hline & & 2. I feel I am accepted in my work group & \\
\hline & & 3. My coworkers back me up when I need it & \\
\hline
\end{tabular}

\section{Data Analysis}

Utilizing Partial Least Square-Structural Equation Modelling (PLS-SEM) approach through SmartPLS software version 3.0 (Ringle et al., 2015), the data analysis was performed in two stages. At the first stage, the reflective and formative measurement model were assessed to determine how well the measurement items relate to the constructs. The second stage entails the testing of the estimates of the structural model for the purposes of hypothesis testing.

\section{The Measurement Model}

Analyses were carried out to test the reliability and construct validity (i.e., convergent validity and discriminant validity) of the measurement. The results of the tests are presented in Tables 3 and 4 which overall demonstrate adequate convergent validity and discriminant validity. 
INTERNATIONAL JOURNAL OF ACADEMIC RESEARCH IN BUSINESS AND SOCIAL SCIENCES Vol. 10, No. 7, July, 2020, E-ISSN: 2222-6990 @ 2020 HRMARS

\section{Figure 2 - Reflective Measurement Model}

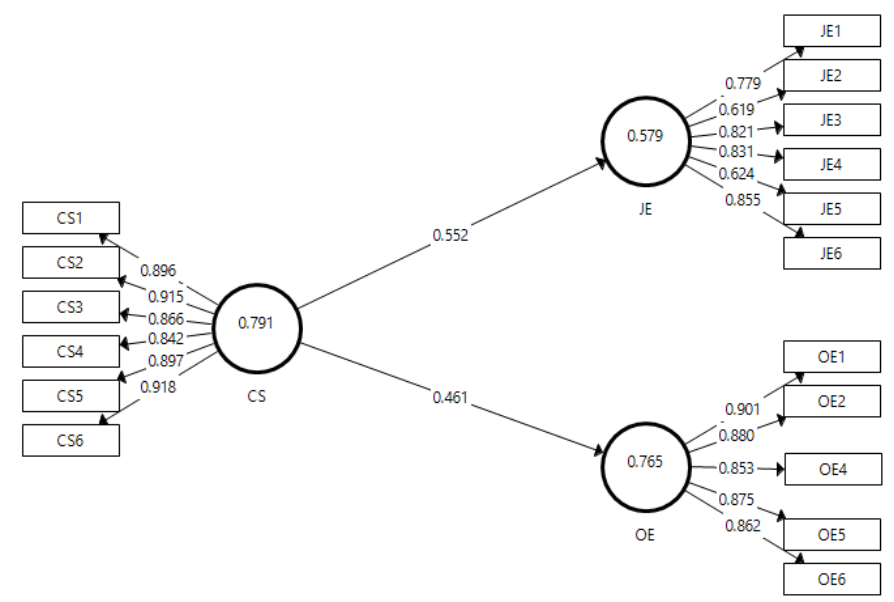

Table 3 - Convergent validity for reflective measurement model

\begin{tabular}{llllll}
\hline Variable & Dimension & Item & Loadings & CR & AVE \\
\hline Employee & Job & JE1 & 0.779 & 0.890 & 0.579 \\
Engagement & Engagement & JE2 & 0.619 & & \\
& (JE) & JE3 & 0.821 & & \\
& & JE4 & 0.831 & & \\
& & JE5 & 0.624 & & \\
\cline { 2 - 6 } & Organisational & OE1 & 0.901 & 0.942 & 0.765 \\
& Engagement & OE2 & 0.880 & & \\
& (OE) & OE4 & 0.853 & & \\
\hline Perceived & Coworkers & CS1 & 0.896 & 0.958 & 0.791 \\
Organisational & Support & CS2 & 0.915 & & \\
Support & (CS) & CS3 & 0.866 & & \\
& & CS4 & 0.842 & & \\
& & CS5 & 0.897 & & \\
& & CS6 & 0.918 & & \\
\hline
\end{tabular}

Note: OE3 item was deleted due to poor loading > .708 (Hair et al., 2010, \& Hair et al., 2014)

As shown in Table 3, the composite reliability values ranged from 0.890 to 0.958 of which exceeded the recommended value of 0.70 (Hair et al., 2010). The average variance extracted (AVE) values were in the range of 0.579 to 0.791 (see Table 3), thus surpassing the suggested threshold value of 0.50 (Hair et al., 2010). These results collectively indicate adequate construct validity for all the study constructs. 


\section{Table 4 - Discriminant Validity}

\begin{tabular}{l|lll}
\hline \multicolumn{2}{l}{ CS } & JE & OE \\
\hline CS & - & & \\
JE & 0.589 & - & \\
OE & 0.491 & 0.717 & -
\end{tabular}

Table 4 reports the results of the discriminant validity test, whereby the square root of the AVE values for each latent variable were found to be higher than the correlation values between the all variables. Following HTMT criterion, these results imply adequate discriminant validity of the study variables at

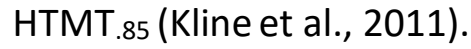

Figure 3 - Redundancy Analysis (Employee Engagement)

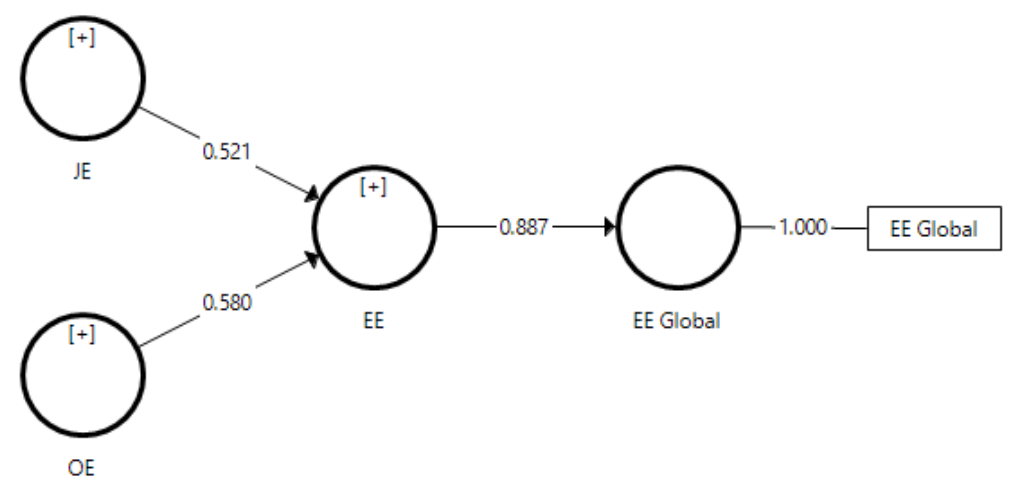

To evaluate formative measurement models, the formative construct must highly correlate with a reflective measure of the same construct. This type of analysis is known as redundancy analysis (Chin, 1998a, 1998b). Specifically, Hair et al., (2017) mention that redundancy analysis can be achieved by using formative construct as an exogenous latent variables predicting the same construct operationalized by reflective indicators or global single item, which summaries the essence of the construct that the formative indicators are intended to measure. It is important that path coefficient linking the constructs should be at least above the threshold of 0.70 to provide support for convergent validity of the formative construct (Hair et al., 2017). Based on the assessment through redundancy analysis, the formative constructs for employee engagement path coefficient is 0.887 which more than 0.70 as shown in Figure 3. Therefore, the formatively measured constructs have sufficient degrees of convergent validity (Klassen $\&$ Whybark, 1999).

\section{The Structural Model}

This section discusses the testing of the structural model to determine whether the hypothesized relationships were supported by the data. Discussions will begin with the testing of the direct effects. In conducting these tests, the standard errors of the constructs were obtained by bootstrapping the sample 5000 times (Henseler et al., 2009). From this bootstrapping process, t-test results are generated to determine the significance of the path model relationships. The indicators used to determine the structural model are path coefficient (Std. Beta) and the coefficient of determination 
INTERNATIONAL JOURNAL OF ACADEMIC RESEARCH IN BUSINESS AND SOCIAL SCIENCES Vol. 10, No. 7, July, 2020, E-ISSN: 2222-6990 @ 2020 HRMARS

$\left(R^{2}\right)$ statistics. Lohmoller (1989) postulates that the path coefficients range greater than 0.1 is acceptable. According to Chin (1998), $R^{2}$ values for endogenous latent variables are assessed based on the following criteria: 0.67 is substantial, 0.33 is moderate and 0.19 is weak. In addition to evaluate the magnitude of the $R^{2}$ values as a criterion of predictive accuracy, $Q^{2}$ value can also be examined. $\mathrm{Q}^{2}$ value is an indicator of the model's predictive relevance. To elaborate, when a PLS-SEM model exhibits predictive relevance, it accurately predicts the data points of the indicators in reflective measurement models of multi-item as well as single-item endogenous constructs. For SEM models, $Q^{2}$ values larger than zero for a specific reflective endogenous latent variable indicate the path model's predictive relevance for a particular construct. Conversely, $Q^{2}$ values of zero or below indicates a lack of predictive relevance (Hair et al., 2014). With regards to effect size, $f^{2}$ values for endogenous latent variables are assessed based on the following criteria: 0.35 is substantial, 0.15 is moderate and 0.02 is weak. Lastly, in gauging lateral collinearity, the variance inflator factor (VIF) need to be less than 3.3 (Diamantopoulos \& Sigauw, 2006) or 5 (Hair et al. 2017).

\section{The Direct Effect}

The results shown in Table 5 confirms that coworkers support was positively related to both job engagement $(\beta=0.552$, t-value $=9.043, p<0.05)$ and organisational engagement $(\beta=0.461, t$ value $=6.146, \mathrm{p}<0.05)$. Thus, both $\mathrm{H}_{1}$ and $\mathrm{H}_{2}$ were supported.

Table 5 - Hypothesis Testing for Direct Effect

\begin{tabular}{l|llllllll}
\hline HYPOTHESIS & DIRECT & STD. & STD. & T- & P- & DECISION & 5\% LL & 95\% \\
& EFFECT & BETA & ERROR & VALUES & VALUES & & & UL \\
\hline $\mathbf{H}_{1}$ & $\mathrm{CS} \rightarrow \mathrm{JE}$ & 0.552 & 0.061 & 9.043 & $0.000^{*}$ & Supported & 0.443 & 0.645 \\
$\mathbf{H}_{2}$ & $\mathrm{CS} \rightarrow \mathrm{OE}$ & 0.461 & 0.075 & 6.146 & $0.000^{*}$ & Supported & 0.332 & 0.590
\end{tabular}

Note: * $p$-value $<0.05$, $t$-value $>1.645$ (one-tailed) as per Hair et al., (2017)

As shown in Figure 4, the $\mathrm{R}^{2}$ value for the relationships between the two components of coworkers support and employee engagement (i.e., job engagement and organisational engagement) were 0.304 and 0.212 , suggesting that $30.4 \%$ and $21.2 \%$ of the variance in job engagement and organisational engagement can be explained by coworkers support respectively. It also indicated that coworkers support has a moderate effect on job engagement whereas coworker support has a weak effect on organisational engagement (Chin, 1998). 


\section{Figure 4 - The PLS Structural Model}

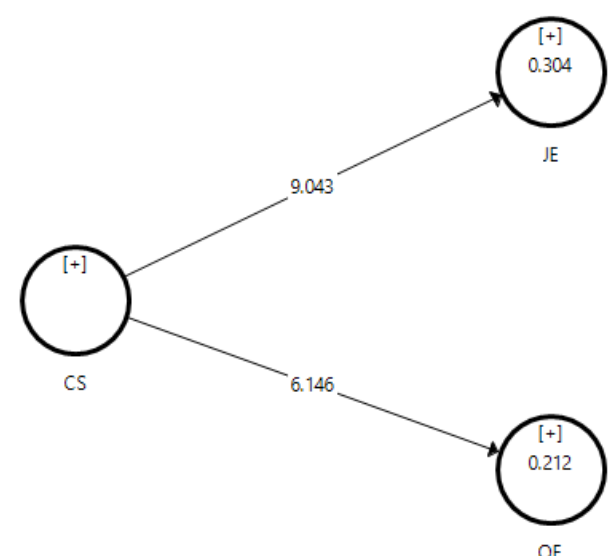

In addition, the $\mathrm{f}^{2}$ values shows that coworkers support has a substantial effect size on job engagement $\left(f^{2}=0.438\right)$ whereas coworkers support has a medium to substantial effect size on organisational engagement $\left(f^{2}=0.269\right)$ according to Cohen (1988). In term of collinearity, the VIF values for both is 1.000 which eliminate the potential collinearity issue as per Diamantopoulos and Sigauw (2006) where VIF values need to be less than 3.3. Besides that, the $Q^{2}$ values for job engagement and organisational engagement were 0.287 and 0.194 respectively. Since the value is above zero, this provides further support for the predictive relevance for the endogenous constructs (Hair et al., 2017).

Table 6 - Effect size and Predictive Relevance

\begin{tabular}{l|lllll}
\hline HYPOTHESIS & $\begin{array}{l}\text { DIRECT } \\
\text { EFFECT }\end{array}$ & $\mathbf{F}^{\mathbf{2}}$ & $\mathbf{R}^{\mathbf{2}}$ & VIF & $\mathbf{Q}^{\mathbf{2}}$ \\
\hline H1 & CS $\rightarrow$ JE & 0.438 & 0.304 & 1.000 & 0.287 \\
H2 & CS $\rightarrow$ OE & 0.269 & 0.212 & 1.000 & 0.194
\end{tabular}

\section{Discussion and Recommendation}

The goal of this research is to examine the impact of coworker support on employee engagement, with 234 offshore employees involved in this research. The findings show that the support of coworkers has a positive relationship to the engagement of offshore workers in Malaysia in both employee engagement dimensions. Moreover, the study has managed to highlight the key findings in the aspect of effect size in which coworkers support has a substantial effect towards job engagement dimension as compared to organisational engagement dimension. This result has demonstrated that the exchange of experiences and the encouragement from the coworkers can be experienced more emotionally towards individual job role instead of influencing employee psychologically present as a member of an organisation. Although the higher management or supervisor was seen as having a higher bearing in term of instilling the organisational support (Wayne, Shore, \& Liden, 1997), coworkers' feedback can be used to supplement the lack of supervisor feedback when required (Eva et. al., 2019). Management can leverage the findings from this study in providing the right culture within the organisation to instill the right values which will promote the coworkers support among the employees in increasing the level of employee engagement as a whole. Therefore, the study reveals that the employees that have a great coworkers support while working 
INTERNATIONAL JOURNAL OF ACADEMIC RESEARCH IN BUSINESS AND SOCIAL SCIENCES

Vol. 10, No. 7, July, 2020, E-ISSN: 2222-6990 @ 2020 HRMARS

at offshore environment in Malaysia O\&G companies had a significant influence towards their engagement especially in job engagement aspect which supported by previous literature (Eva et. al., 2019).

\section{Limitation of Study and Future Direction}

This study is not without limitations as the data were collected from the employees that are working at oil and gas offshore facilities in Malaysia. Hence, it cannot be generalized to other countries or industry in Malaysia. Context wise, since the study is conducted among offshore employees, the environment may be different as compared to those employees working at onshore. Thus, we propose future study should also evaluate the impacts of coworkers support and employee engagement on other upstream and downstream industries to further generalize the findings. Based on research conducted by Harun et al., (2014), there were social gap observed between lower level employees with the executive level at the O\&G facilities. Thus, future studies should also consider to examine whether supervisor support and management support at offshore location play an important role in enhancing the level of employee engagement.

\section{References}

Addae, H. M., Parboteeah, K. P., \& Velinor, N. (2008). Role stressors and organizational commitment: Public sector employment in St Lucia. International Journal of Manpower.

Albdour, A. A., Altarawneh, I. I. (2014). Employee engagement and organizational commitment: Evidence from Jordan

Allen, N. J., \& Meyer, J. P. (1990). The measurement and antecedents of affective, continuance and normative commitment to the organization. Journal of Occupational Psychology.

Beardwell, J., \& Thompson, A. (2014). Human Resource Management: A Contemporary Approach (7th ed.). Harlow: Pearson Education Limited.

Blau, P. M. (1964). Exchange and power in social life. 1964, New York: Wiley

Chin, W. W. (1998). Issues and opinion on structural equation modeling. MIS Quarterly, March, viixvi.

Cohen, J. (1988). Statistical power analysis for the behavioral sciences (2nd ed.). Hillsdale, NJ: Lawrence Earlbaum Associates.

Diamantopoulos, A., \& Siguaw, J. A. (2006). Formative versus reflective indicators in organizational measure development: A comparison and empirical illustration. British Journal of Management, 17(4), 263-282.

Eisenberger, R., and Huntington, R. (1986). Perceived Organizational Support. Journal of Applied Psychology.

Eva, N., Meacham, H., Newman, A., Schwarz, G., \& Tham, T. L. (2019). Is coworker feedback more important than supervisor feedback for increasing innovative behavior? Human Resource Management, 58(4), 1-14. doi:10.1002/hrm.21960

Etzioni, A. (1975). A comparative analysis of complex organizations. New York: Free Press.

Faul, F., Erdfelder, E., Lang, A-G., \& Buchner, A. (2007). G*Power 3. A flexible statistical power analysis program for the social, behavioral and biomedical sciences. Behavior Research Methods. 39, 175-191. 
INTERNATIONAL JOURNAL OF ACADEMIC RESEARCH IN BUSINESS AND SOCIAL SCIENCES Vol. 10, No. 7, July, 2020, E-ISSN: 2222-6990 @ 2020 HRMARS

Gellatly, I. R., Meyer, J. P., \& Luchak, A. A. (2006). Combined effects of the three commitment components on focal and discretionary behaviours: A test of Meyer and Herscovitch's propositions. Journal of Vocational Behavior, 69, 331-345.

Hair, J. F., Hult, G. T. M., Ringle, C. M., \& Sarstedt, M. (2014). A Primer on Partial Least Squares Structural Equation Modeling (PLS-SEM). Thousand Oaks, California: Sage Publications.

Hair, J. F., Hult, G. T. M., Ringle, C. M., Sarstedt, M., \& Thiele, K. O. (2017). Mirror, mirror on the wall: A comparative evaluation of composite-based structural equation modelling methods. Journal of the Academy of Marketing Science, 45, 616-632.

Hakanen, J. J., Schaufeli, W. B., Ahola, K. (2008). The Job Demands-Resources model: A three-year cross-lagged study of burnout, depression, commitment, and work engagement.

Harter, J. K., Schmidt, F. L., Hayes, T. L. (2002). Business-unit-level relationship between employee satisfaction, employee engagement, and business outcomes: a meta-analysis.

Haryanni, H., Rohani, S., Mumtaz, M., Mohamed, B., \& Azrai, A. (2014). Job Satisfaction, Organizational Commitment and Stress among Offshore Oil and Gas Platform Employees. Asian Social Science. 10. 28. 10.5539/ass.v10n11p28.

Hayduk, L. A., \& Littvay, L. (2012). Should researchers use single indicators, best indicators, or multiple indicators in structural equation models? BMC Medical Research Methodology.12(159).

Henseler, J., Ringle, C. M., \& Sarstedt, M. (2015). A new criterion for assessing discriminant validity in variance-based structural equation modeling. Journal of the academy of marketing science, 43(1), 115-135.

Jaros, S. (2015). Meyer and Allen model of organizational commitment: Measurement issues. The Icfai Journal of Organizational Behavior.

John, P. M., \& Natalya, M. P. (2010) Normative commitment in the workplace: A theoretical analysis and re-conceptualization

Kahn, W. A. (1990). Psychological conditions of personal engagement and disengagement at work. Academy of Management Journal, 33(4), 692-724.

Kanter, R. M. (1968). Commitment and social organization: A study of commitment mechanisms in utopian communities. American Sociological Review, 33, 499-517.

Khodakarami, N., and Dirani, K. (2020), "Drivers of employee engagement: differences by work area and gender", Industrial and Commercial Training, Vol. 52 No. 1, pp. 81-91. https://doi.org/10.1108/ICT-06-2019-0060

Kline, R. B. (2011). Principles and practice of structural equation modeling. New York: Guilford Press.

Lohmoller, J. B. (1989), Latent Variable Path Modeling with Partial Least Squares, Physica, Heidelberg, Germany.

Martín, S. S. (2008). Relational and economic antecedents of organisational commitment

May, G. R. L., Harter, L. M. (2004). The psychological conditions of meaningfulness, safety and availability and the engagement of the human spirit at work

Meyer, J. P., \& Parfyonova, N. M. (2010). Normative commitment in the workplace: A theoretical analysis and re-conceptualization. Human Resource Management Review, 20, 283-294.

Newstrom, J. W. (2015). Organization behavior: human behavior at work, 12tth edition. Boston: McGraw Hill.

Ringle, C., Wende, S., \& Will, A. (2015). SmartPLS 3.2.9. Retrieved from http://www.smartpls.com 
INTERNATIONAL JOURNAL OF ACADEMIC RESEARCH IN BUSINESS AND SOCIAL SCIENCES Vol. 10, No. 7, July, 2020, E-ISSN: 2222-6990 @ 2020 HRMARS

Roldán, J. L., \& Sánchez-Franco, M. J. (2012). Variance-based structural equation modeling: Guidelines for using partial least squares. In M. Mora, O. Gelman, A. L. Steenkamp, \& M. Raisinghani (Eds.), Research methodologies, innovations and philosophies in software systems engineering and information systems (pp. 193-221). Hershey, PA: IGI Global.

Roussenau, D. M. (1995), Promises in Action: Psychological Contracts in Organizations, Sage, Newbury Park, CA.

Rothbard, N. (2001). Enriching or depleting? The dynamics of engagement in work and family roles Saks, A. M. (2006). Antecedents and consequences of employee engagement. Journal of Managerial Psychology.

Schaufeli, W. B., Salanova, M., González-Roma, V. A., \& Bakker, A. B. (2002). The Measurement of Engagement and Burnout: a Two Sample Confirmatory Factor Analytic Approach. Journal of Happiness Studies.

Scholl, R. W. (1981). Differentiating organizational commitment from expectancy as a motivating force. Academy of Management Review, 6, 589-599.

Sonnentag, S. (2011). Research on work engagement is well and alive. European Journal of Work and Organizational Psychology. https://doi.org/10.1080/1359432X.2010Rothbard, N. P. (2001). Enriching or Depleting? The Dynamics of Engagement in Work and Family Roles. Administrative Science Quarterly.

Wachira, J. M. (2013). Relationship between employee engagement and commitment in barclays bank of Kenya

Wayne, S. J., Shore, L. M., \& Liden, R. C. (1997). Perceived organizational support and leadermember exchange. A social exchange perspective. Academy of Management Journal, 40(1), 82-111. doi:10.2307/257021

Wiener, Y. (1982). Commitment in organizations: A normative view. Academy of Management Review, 7, 418-42

Wiener, Y., \& Gechman, A. S. (1977). Commitment: A behavioral approach to job involvement. Journal of Vocational Behavior. 